\title{
Development of Type Control Guidelines for the Old Town District of Hsinchu City
}

\author{
Yi-Yin Tsai \\ Department of Architecture and Urban Planning, Chung Hua University, No. 707, Sec. 2, Wufu Rd., Hsinchu, Taiwan \\ E-mail: yiyint@gmail.com \\ www.chu.edu.tw
}

\begin{abstract}
The concept of "Building Type Control" was employed to establish hierarchical design guidelines for the urban regeneration process. GIS was used to manage and map environmental database as visual reference tool. Existing building regulations and urban design policies were reviewed to set out limitation and development vision for the study district, type control zones were set out with control design guidelines respectively to serve as a sufficient reference tool to assist design decision making in the urban regeneration process.
\end{abstract}

Keywords: Type Control, Design Guideline, Urban Regeneration, Urban Design

\section{Introduction}

Addressing urban regeneration in an old town district of a compact urban city is a complex task, which involves consideration of many interconnected issues. Consequently, the subject of urban regeneration or sustainable urban development with regard to the existing building fabric requires a systematic controlling hierarchies and urban design guidelines to be employed more sufficiently in the design process in fulfilling the vision and requirements of future urban development.

\subsection{Research Subject}

This research selected the old town district of Hsinchu City to be the research subject. Documentation of the subject background data was carried out first with onsite interviews to collect basic information of the research area's existing condition. Through understanding the historical development of the site, the cultural landscape features and changes over years; it was clear that a set of sufficient design guidelines or regulations is necessary to ensure the quality of urban environment through the development process. The study attempts to employ the concept of "type control" to formulate a set of rules in regulating features of each individual building, as well as the overall appearance of building streetscape. The concept of "typology" was used to identify the development types of various building district to set the zoning types initially. The type control design guidelines were set out accordingly.

\section{Method}

\subsection{Typology}

According to the Oxford Advanced Learners Dictionary of Current English, the word "Typology" is explained as to distinguish between different types of type system 
[1]. In the field of architectural discourse, in terms of typology, it is defined as a way of understanding and thinking. In the eighteenth century, building typology is recognized as the method of a continuous and uniform system for the classification process for architectural building. According to M. Bandini [2], the concept of typology can be summarized as three aspects: the first one to be the method of city reading which emphasizes the integrated nature of the city and explore the morphology of city with the building types; the second aspect is concerned with the cultural perspective represented by G. Argan which addresses urban typology as a method consists of various city architectural styles; the third aspect, directed by Quatremere de Quincy and represented by O. M. Ungers and others, defines typology as the production tool and production theory of architecture.

In terms of research, Johnson and Christensen [3] defined this concept as a classification system that split something into a number of different types or kinds. Grix [4] refers to the concept as dividing the study objects into many types, where the attributes of each of the type are mutually exclusive to each other but together as a exhaustive system. Since one type only requires one property; typology can be used in a variety of variables under various circumstances. In typology, a special order can be derived based on the research purpose and the research phenomena, and this order is able to set limitation on the methods of data interpretation. Thus, a hierarchical type control design guidelines could be set out for the regeneration process.

\subsection{GIS Data Input}

Employing the type model structure developed through literature review, GIS software was used to construct the façade feature database to illustrate the existing building condition of the study subject. Different colors were used to represent different "sub-type" or "sub-type item" of the data information. An example of the GIS mapping of a sub-type feature is shown in Figure 1.

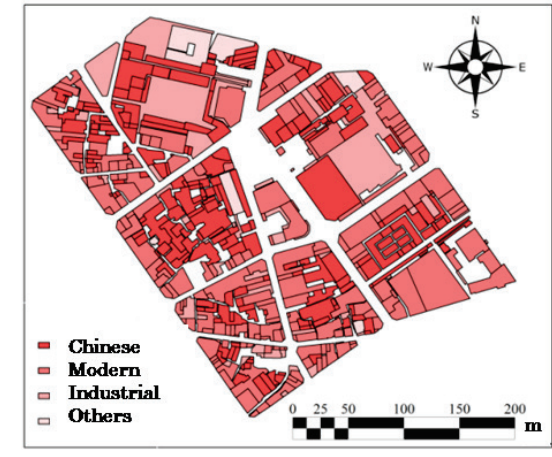

Figure 1. GIS mapping of the "Style" sub-type feature under the "Basic Element" sub-type of the existing building fabric condition of the study subject.

\subsection{Policy Review}

Existing government regulation and policy addressing topic of urban regeneration was first reviewed and summarized to formulate the development vision for the research subject in constructing the type control guidelines. Both the land-use zoning control regulations, and the urban design regulations of the three major city in Taiwan, the Hsinchu City, the Taichung City and the Tainan City, were reviewed to understand the basic control regulation each city used in regulating and controlling the appearance of building design in different urban district in order to establish a set of type control guideline for various urban district.

\section{Result}

\subsection{Type Control Guidelines}

The old town district of Hsinchu City serves as the urban development center of the city, it hosts most of the daily activities of the local people as well as the major tourist attractions. It has a mixture of historical and modern buildings, as well as a mixture of residential, commercial, civic, religious and governmental building functions. Thus, four type control zones were set out as following:

(1) District I: Urban Commercial \& Historical Fringe Zone.

District I is the fringe of the historical street zone and the newly urban commercial development area. The 
district is closed to the main urban activity traffic road and serves as a landmark for the newly developed area. Creating new city image and connecting pedestrian activities are the key considerations for setting up control guidelines for the district.

(2) District II: Historical Street Zone.

This district is a historical street control zone; the old buildings were set to be preserved and maintained according to its original historical appearance. The main control guidelines were set to emphasize on the building envelope and façade appearance type controls.

(3) District III: Art \& Culture Activity Zone.

District III is designated to be the art and culture activity control zone within the old town area of Hsinchu City as the cultural art museum is located at the center of the district. Since the cultural art museum has just been listed as the City's historical building, and the museum was designed to host modern exhibition; the district was set to consider both the idea of historical preservation as well as future modern developments.

(4) District IV: Monumental \& Local Business Zone.

Type IV district is classified as monumental and local business zone due to several important existing buildings within the periphery area; including the main religious temple, the Cheng Huang Temple, the city's central vegetable market, and the traditional shopping center which are all in need to be refurbished and preserved under city's urban renewal project. The local restaurant business is also very active within this district, which serves as important tourist attraction and local food cultural identity. Design guidelines for this district were set to target at preservation and maintenance of the local identity and the sense of place.

\section{Conclusions}

This research established a systematic type control guidelines with the concept of typology to integrate city's urban development plan with local building regulations. The results could serve as a future reference for Hsinchu City government as design guidelines for specific regional planning policy to maintain the characteristic of local building style in the process of urban regeneration. In addition, the urban environmental analysis of this research could serve as a reference for future researches in the field of environmental management when dealing with both historical and modern urban district.

Table 1. Type Control Guidelines for District I-IV

\begin{tabular}{|c|c|c|c|c|}
\hline Four & & $\overline{\mathrm{ol} \mathrm{Z}}$ & & \\
\hline${ }^{2}=$ & 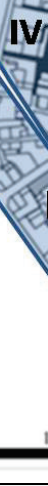 & 150 & $\mathbf{m}$ & 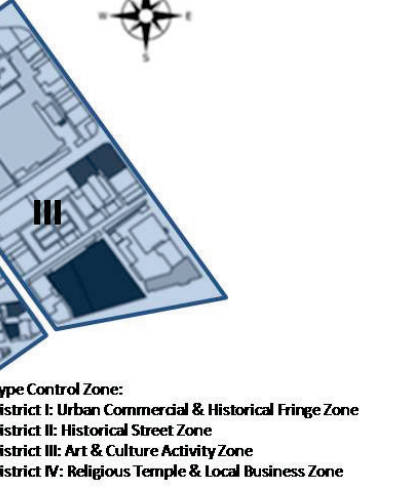 \\
\hline $\begin{array}{l}\text { Main } \\
\text { Type }\end{array}$ & \multicolumn{2}{|c|}{$\begin{array}{l}\text { Sub-Type / } \\
\text { Type Item }\end{array}$} & $\begin{array}{l}\text { Dist } \\
\text { rict }\end{array}$ & Control Guidelines \\
\hline \multirow{9}{*}{ 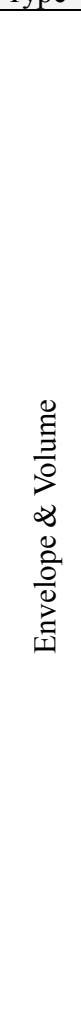 } & \multirow{7}{*}{ 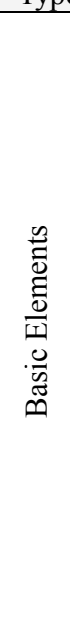 } & \multirow{4}{*}{ Style } & I & $\begin{array}{l}\text { Western style with local } \\
\text { material. }\end{array}$ \\
\hline & & & II & $\begin{array}{l}\text { Traditional Chinese arcade } \\
\text { style. }\end{array}$ \\
\hline & & & III & Modern style \\
\hline & & & IV & $\begin{array}{l}\text { Traditional Chinese } \\
\text { monumental style }\end{array}$ \\
\hline & & & $\begin{array}{l}\text { I } \\
\text { III }\end{array}$ & $\begin{array}{l}\text { No limitation, but maintain the } \\
\text { overall sense of volume of the } \\
\text { streetscape. }\end{array}$ \\
\hline & & $\begin{array}{l}\text { Geom } \\
\text { etry } \\
\text { and } \\
\text { Shane }\end{array}$ & II & $\begin{array}{l}\text { Arch style arcade with straight } \\
\text { line distributed on the building } \\
\text { elevation. }\end{array}$ \\
\hline & & & IV & $\begin{array}{l}\text { Building shapes shall consider } \\
\text { the Taiwanese traditional } \\
\text { temple style. }\end{array}$ \\
\hline & 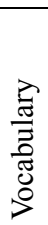 & $\begin{array}{l}\text { Buildi } \\
\text { ng } \\
\text { Base }\end{array}$ & $\begin{array}{l}\text { I } \\
\text { II } \\
\text { III } \\
\text { IV }\end{array}$ & $\begin{array}{l}\text { Building's ground level shall } \\
\text { reserve pedestrian space. } \\
\text { Encourage the usage of } \\
\text { different materials, wall } \\
\text { treatments and volume } \\
\text { variations. }\end{array}$ \\
\hline & 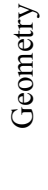 & $\begin{array}{l}\text { Rooft } \\
\text { op }\end{array}$ & $\begin{array}{l}\text { I } \\
\text { II } \\
\text { III } \\
\text { IV }\end{array}$ & $\begin{array}{l}\text { Rooftop machinery and } \\
\text { equipment should be sheltered } \\
\text { and should use similar } \\
\text { material as building itself with } \\
\text { appropriate design. }\end{array}$ \\
\hline
\end{tabular}


Table 1. (Continued)

\begin{tabular}{|c|c|c|c|c|}
\hline \multirow{9}{*}{ 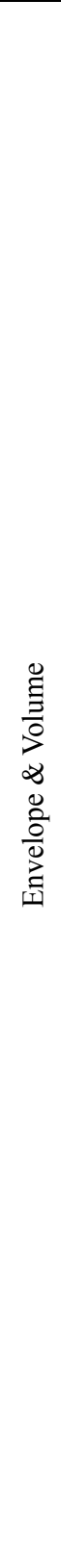 } & \multirow{5}{*}{ 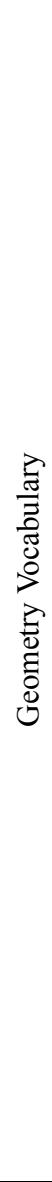 } & $\begin{array}{l}\text { Elevat } \\
\text { ion }\end{array}$ & $\begin{array}{l}\text { I } \\
\text { II } \\
\text { III } \\
\text { IV }\end{array}$ & $\begin{array}{l}\text { Balcony or extruded parts of } \\
\text { the building shall not exceed } \\
\text { the building line and shall not } \\
\text { exceed more than } 50 \mathrm{~cm} \text { of the } \\
\text { external walls. }\end{array}$ \\
\hline & & \multirow{4}{*}{$\begin{array}{l}\text { Color } \\
\& \\
\text { Materi } \\
\text { al }\end{array}$} & I & $\begin{array}{l}\text { Building's front façade color } \\
\text { could be and distinctive. } \\
\text { Building identity and harmony } \\
\text { of the overall streetscape } \\
\text { should be emphasized. }\end{array}$ \\
\hline & & & II & $\begin{array}{l}\text { Building's front façade color } \\
\text { should mainly be brick red or } \\
\text { stone gray. } \\
\text { Building materials should } \\
\text { have a traditional material } \\
\text { texture appearance, or use } \\
\text { facade tile, clear-finished } \\
\text { brick, pebble stones or other } \\
\text { similar materials. }\end{array}$ \\
\hline & & & III & $\begin{array}{l}\text { Building's main façade } \\
\text { material shall consider its } \\
\text { permanence and } \\
\text { suitability to the local } \\
\text { climate conditions. }\end{array}$ \\
\hline & & & IV & $\begin{array}{l}\text { The building volume color } \\
\text { shall primarily be silvery } \\
\text { white, light gray or other } \\
\text { light color tones. } \\
\text { Composition of various } \\
\text { color tones and shades } \\
\text { could be used. }\end{array}$ \\
\hline & \multirow{4}{*}{ 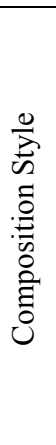 } & $\begin{array}{l}\text { Openi } \\
\text { ng } \\
\text { Ratio }\end{array}$ & $\begin{array}{l}\text { I } \\
\text { II } \\
\text { III } \\
\text { IV }\end{array}$ & $30-60 \%$ \\
\hline & & Functi & $\begin{array}{l}\mathrm{I} \\
\mathrm{II} \\
\end{array}$ & $\begin{array}{l}\text { Residential and commercial } \\
\text { mixed use. }\end{array}$ \\
\hline & & on & $\begin{array}{l}\text { III } \\
\text { IV }\end{array}$ & Commercial use \\
\hline & & $\begin{array}{l}\text { Confi } \\
\text { gurati } \\
\text { on }\end{array}$ & $\begin{array}{l}\text { I } \\
\text { II } \\
\text { III } \\
\text { IV }\end{array}$ & Align with the street. \\
\hline \multirow{6}{*}{ 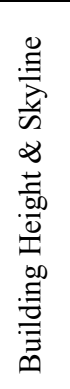 } & \multirow{3}{*}{\multicolumn{2}{|c|}{ Appearance }} & $\begin{array}{l}\text { I } \\
\text { II }\end{array}$ & $\begin{array}{l}\text { Uniform skyline with proper } \\
\text { setback arcade area. }\end{array}$ \\
\hline & & & III & $\begin{array}{l}\text { High-rise building with } \\
\text { landmark image. }\end{array}$ \\
\hline & & & IV & $\begin{array}{l}\text { Mix of building heights with } \\
\text { local recognition. }\end{array}$ \\
\hline & \multirow{3}{*}{\multicolumn{2}{|c|}{ Landmark }} & $\mathrm{I}$ & Street corners. \\
\hline & & & $\begin{array}{l}\text { II } \\
\text { IV }\end{array}$ & Local temple. \\
\hline & & & III & Local civic building. \\
\hline
\end{tabular}

\begin{tabular}{|c|c|c|c|c|}
\hline \multirow{2}{*}{ 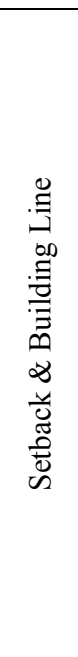 } & \multicolumn{2}{|c|}{$\begin{array}{l}\text { Length } \\
\text { Ratio }\end{array}$} & I & $\begin{array}{l}\text { Arcade's ground level should } \\
\text { align with the sidewalk, in the } \\
\text { case of no sidewalk, it should } \\
\text { be } 10-20 \mathrm{~cm} \text { higher than the } \\
\text { traffic road with no stairs and } \\
1 / 40 \text { slope ratio. }\end{array}$ \\
\hline & \multicolumn{2}{|c|}{ Area Ratio } & $\begin{array}{l}\text { II } \\
\text { III } \\
\text { IV }\end{array}$ & $\begin{array}{l}\text { Setback arcade without } \\
\text { overhead coverage should } \\
\text { incorporate appropriate } \\
\text { plantation and greenery } \\
\text { Pedestrian sidewalk width } \\
\text { shall not be less than } 2.5 \mathrm{~m} \text {. } \\
\text { Arcade height shall not be less } \\
\text { than } 3 \mathrm{~m} \text {. } \\
\text { Building façade facing street } \\
\text { less than } 7 \mathrm{~m} \text { should setback at } \\
\text { least } 0.5 \mathrm{~m} \text { from the building } \\
\text { line. }\end{array}$ \\
\hline \multirow{7}{*}{ 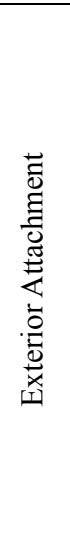 } & \multirow{5}{*}{ 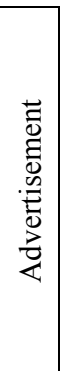 } & Size & \multirow{3}{*}{$\begin{array}{l}\text { I } \\
\text { II } \\
\text { III } \\
\text { IV }\end{array}$} & $\begin{array}{l}\text { Vertical length shall not be } \\
\text { more than } 6 \mathrm{~m} \text {. }\end{array}$ \\
\hline & & Color & & $\begin{array}{l}\text { Harmony with the front } \\
\text { elevation. }\end{array}$ \\
\hline & & $\begin{array}{l}\text { Locati } \\
\text { on }\end{array}$ & & $\begin{array}{l}\text { The lower part should not be } \\
\text { less than } 3 \mathrm{~m} \text { from the ground. }\end{array}$ \\
\hline & & \multirow{2}{*}{ Style } & $\begin{array}{l}\mathrm{I} \\
\mathrm{IV}\end{array}$ & Front-facing style. \\
\hline & & & $\begin{array}{ll}\text { II } \\
\text { III }\end{array}$ & Side-facing style. \\
\hline & \multicolumn{2}{|c|}{ Canopy } & $\begin{array}{l}\text { I } \\
\text { II }\end{array}$ & $\begin{array}{l}\text { Rain coverage and sun } \\
\text { shading should not be less } \\
\text { than } 6 \mathrm{~m} \text {. }\end{array}$ \\
\hline & \multicolumn{2}{|c|}{$\begin{array}{l}\text { Additional } \\
\text { Equipment }\end{array}$} & IV & $\begin{array}{l}\text { Should not be placed on the } \\
\text { front façade. }\end{array}$ \\
\hline
\end{tabular}

\section{Acknowledgment}

The author would like to thank The Ministry of Science and Technology of Taiwan financially supporting this research under the Contract No. NSC 102-2410-H-216010 .

\section{References}

1. A. S. Hornby, S. Wehmeier, Oxford advanced learner's dictionary of current English. Oxford: Oxford University Press, 2000.

2. B. Micha, Typology as a Form of Convention, AA Files, 6, pp. 73-82, 1984.

3. B. Johnson, and L. Christensen, Educational research, Thousand Oaks, CA: Sage, $3^{\text {rd }}$ ed., 2008.

4. J. Grix, The foundations of research, 2008. 